Acta Universitatis Lodziensis

\title{
Understanding cannabinoid receptors: structure and function
}

\author{
ANGElikA ANDRZEJEWSKA ${ }^{1}$, Klaudia StASZAK ${ }^{1}$, MARTA KACZMAREK-RYŚ ${ }^{1}$, \\ RYSZARD SŁOMSKI ${ }^{1,2}$, SZYMON HRYHOROWICZ*1 \\ ${ }^{1}$ Institute of Human Genetics, Polish Academy of Sciences, Strzeszynska 32, 60-479 Poznan, Poland \\ ${ }^{2}$ Department of Biochemistry and Biotechnology, University of Life Sciences, Dojazd 11, 60-632 Poznan, \\ Poland \\ E-mail: szymon.hryhorowicz@igcz.poznan.pl
}

\begin{abstract}
The endocannabinoid system (ECS) consists of the endocannabinoids, cannabinoid receptors and the enzymes that synthesize and degrade endocannabinoids. The whole EC system plays an important role in the proper functioning of the central and autonomic nervous system. ECS is involved in the regulation of the body energy and in the functioning of the endocrine system. It can affect on the regulation of emotional states, motoric movement, operations of the endocrine, immune and digestive system. Many of the effects of cannabinoids are mediated by $\mathrm{G}$ coupled -protein receptors: CB1, CB2 and GPR55 but also of transient receptor potential channels (TRPs) which not only induce the sensation of pain but also support inflammation via secretion of pro-inflammatory neuropeptides. In this review work we briefly summarize the role and action of cannabinoid receptors $\mathrm{CB} 1$ and $\mathrm{CB} 2$, protein-coupled receptor 55 (GPR55) and transient receptor potential vanilloid 1 (TRPV1).
\end{abstract}

KEY WORDS: cannabinoid receptors, CB1, CB2, TRPV1, GPR55

\section{Introduction}

Cannabinoid receptors are one of the most abundant neuronal receptors that are linked through $\mathrm{G}$ proteins (the guaninenucleotide-binding proteins) to the effectors system (called G-protein coupled receptors, GPCRs). This group includes two well characterized types of receptors - CB1 and CB2. They are part of the endocannabinoid system (ECS), consisting of lipophilic substances stimulating their function endocannabinoids and exogenous agonists, as well as enzymes governing the synthesis and degradation (Pawlak et al., 2011). In recent years, researches have provided evidence that the system is more complicated and additional receptor types should exist to explain ligand activity in 
many physiological processes. To date other types of cannabinoid receptors, non$\mathrm{CB} 1$ and non- $\mathrm{CB} 2$, have been reported such as orphan GPR55 and TRPV1 receptors, which could explain not completely understood pathway system (Bisogno et al., 2001; Ryberg et al., 2007; Befort, 2015).

It is known that mammalian tissues may produce endogenous ligands of cannabinoid receptors. First discovered the substance of this type was the amide derivative of arachidonic acid arachidonoyl ethanolamide - AEA, which was called anandamide. Later was discovered another endocannabinoid of lipid structure - 2-arachidonyl glycerol (2AG). These substances can activate receptors and are synthesized on demand in response to elevations of intracellular calcium. Studies show that repeated administration of cannabinoid receptor agonists may cause the development of tolerance to some of their effects (Pertwee, 2006; Pertwee, 2009).

Exogenous cannabinoids has been termed substances that are extracted from the marijuana plant Cannabis sativa or are synthesized artificially. The most popular examples of these substances are cannabinol $(\mathrm{CBN})$, cannabidiol (CBD) and delta-9-tetrahydrocannabinol $(\Delta 9$ THC). The last of them is the major immunomodulatory and psychoactive component of the marijuana (Cabral and Griffin-Thomas, 2009).

The discovery of $\mathrm{CB} 1$ and $\mathrm{CB} 2$ receptors was followed by the development of CB1- and CB2-selective cannabinoid receptor antagonists. These substances block the normal operation of the receptor and may weaken or suppress agonist (Pertwee, 2006).

The whole endocannabinoid system plays an important role in the proper functioning of the central and autonomic nervous system. The reason for such action of cannabinoids is their easy passage through the blood-brain barrier.
ECS is involved in the regulation of the body energy and in the functioning of the endocrine system. It can affects on the regulation of emotional states, motoric movement, operations of the endocrine, immune and digestive system (Komorowski and Stępień, 2007). This system plays a major role in the control of pain, in reward processing and in the development of addiction (Befort, 2015).

Although the relationship between activity of cannabinoid receptors and cell proliferation is not fully understood. It is known that certain agonists of these receptors, including anandamide, inhibit proliferation of cultured human breast cancer cells. It is worth noting, that the tests on the effectiveness of cannabinoids in the treatment of neurodegenerative diseases (such as Parkinson disease) are carried out, because of their neuroprotective properties (Konarska and Ellert, 2004).

\section{Methods}

Publication search was performed in Medline and PubMed database. The key words used were cannabinoids receptors, cannabinoids, CB1, CB2, GPR55, TRPV1. We decided to use both, the older papers describing the discovery of cannabinoid receptors and more recent publications, describing possible new interactions between potential novel receptors and cannabinoids.

\section{Cannabinoid receptor type 1 - CB1 receptor}

$\mathrm{CB} 1$ and $\mathrm{CB} 2$ receptors belong to Gprotein coupled receptor (GPCR) family. The cannabinoid receptor type 1 is primarily located in central and peripheral nervous system. The CB1 receptors expressed predominantly in the brain. The highest density of cannabinoids binding sites are in first and fourth layer of the cerebral cortex, hypothalamus, pyramidal cell layer of the hippocampus, pariaqueductal gray dorsal horn and in the 
limbic system. These areas associated the endocannabinoid system with memory processes, modulation of emotional states and mobility, as well as anticonvulsant properties of cannabinoids. CB1 receptors are also observed in basal ganglia and cerebellum but in lower density than for example in rodents. Lower density of CB 1 is also observed in the structure of the vental tegmental area and nucleus accumbens, which is responsible for the development of happiness and reward feelings, also known as reward system (Komorowski and Stępień, 2007).

Initially it was believed that these receptors are present only in the brain, but their presence in peripheral locations was also demonstrated. CB1 receptors were observed in inter alia in the pituitary gland, immune cells, tissues, digestive tract, reproductive system, heart, lung, intestine, tonsil, thymus, spleen and placenta (Rutkowska and Jamontt, 2005; Ryberg et al., 2007; Busquets-Garcia et al., 2016).

The cannabinoid receptor type 1 is the product of CNR1 gene expression. Medium sized protein is $52858 \mathrm{Da}$ and it is composed of 472 amino acids (Pawlak et al., 2011). For the first time the complementary DNA of this receptor was isolated from a cDNA library of rat cerebral cortex in 1990 (Konarska and Ellert, 2004; GeneCards). In 1995, Shire and his team have isolated a shorter isoform of the receptor - composed of 411 amino acids, as a result of deletion of 167 base pairs in the nucleotide sequence. This change resulting protein product, a variant CB1A, has a molecular weight of $46 \mathrm{kDa}$ (Shire et al., 1995). In 2004, Ryberg et al. identified a second isoform of the receptor CB1 - a variant CB1B - with a molecular weight of $49 \mathrm{kDa}$, constructed of 439 amino acids. Both variants have altered the ability of the ligand binding and activation as compared to the original length transcript (Ryberg et al., 2005).

The construction of $\mathrm{CB} 1$ receptors is well characterized, comprising a single, highly fold to polypeptide chain. Chain completes its structure through the cell membrane seven times to form seven hydrophobic transmembrane domains (TM I - TM VII) (Kazula, 2009). Figure 1 shows a general scheme for the construction of $\mathrm{CB} 1$ receptor in human.

Figure 1. Construction of cannabinoid receptor type 1 (CB1). The numbers at the beginning (1) and end (472) of the chain indicate the direction of numbers of amino acids. Terminal residues, amino $(\mathrm{N}-)$ and carboxy $(\mathrm{C}$ ), transmembrane domains (TM I-VII), intracellular (ic) and extracellular (ec) loops are also marked.

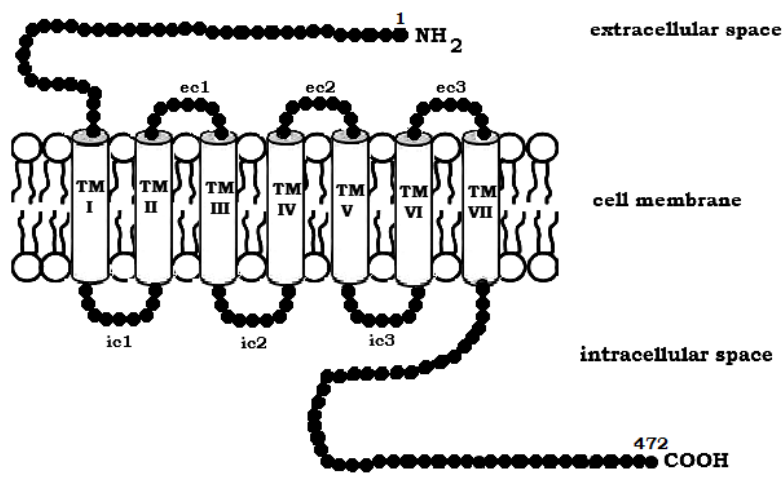

Polypeptide chain ends of the receptor, are located on different side of the cell membrane. The N-terminus is located outside the cell and the $\mathrm{C}$-terminus have 
an intracellular localization - in the cytoplasm. In addition, the receptor has in its structure a three extracellular and three intracellular loops. The second extracellular loop and the third transmembrane domain may bind CB1 agonists, while the third loop, which is located inside the cell, binds the inhibitory protein G. Construction of receptor shows a significant interspecies preservation. Comparing the nucleotide and amino acid structures of the $\mathrm{CB} 1$ receptor in human and rat, the similarity is equal respectively to $93 \%$ and $97 \%$ (Konarska and Ellert, 2004; Kazula, 2009).

The primary activity of cannabinoid receptors is the regulation of the permeability of adjacent ion channels. This is done through interaction with the trimeric protein Gi/Go, which act as adapter proteins. General scheme of functioning $\mathrm{CB} 1$ receptor is shown in Figure 2.

Figure 2. Diagram of the mechanism of signal transduction by the CB1 receptor in presynaptic bulb (based on Ameri, 1999 and Konarska, Ellert, 2004).

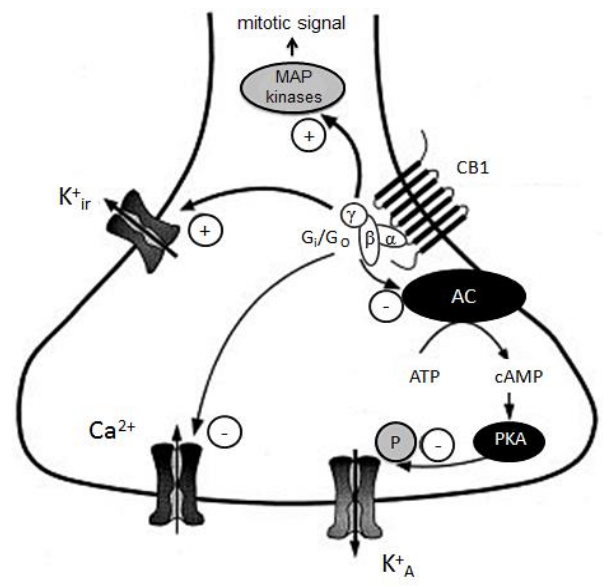

Start of the signalling reaction is conditioned by the appearance of the appropriate agonist (e.g. THC) or by an endogenous ligand (e.g. anandamide and 2-arachidonoylglycerol) which binds to the receptor directly (Nicoll et al., 2012).

When the ligand join the outer loop of the receptor, located in the presynaptic membrane, following its stimulation by changes the conformation of the internal receptor. The result is a $\mathrm{Gi} / \mathrm{Go}$ protein attachment to the inner loop of the CB1 receptor, which then, due to the exchange of guanosine 5'-diphosphate (GDP) by guanosine 5'-triphosphate (GTP) dissociate an active subunits $\alpha, \beta$ and $\gamma$. The result of the $\mathrm{G}$ proteins activation is the start of multiple MAP kinase cascades (mitogen-activated protein kinase), which play a role i.e.: in gene expression, division, differentiation and apoptosis of cells. Cascade of reactions is responsible for inhibition of adenylyl cyclase (AC) activity, which reduces the amount of cyclic AMP (Cyclic adenosine 3 ', 5'monophosphate, cAMP), or intracellular relay II row. This can lead to a reduction of protein kinases (PKA), which are responsible for phosphorylation of the potassium channel KA (depending on voltage) causing a greater flow of these ions. Activation of G-proteins, by CB1 receptors, directly produces inhibition of calcium channels, and activation of 
potassium channels Kir and thus transporting accordance with the electrochemical gradient. As a result the above signal cascade, occurs to a reduced release of neurotransmitters from presynaptic terminals (Sullivan, 2000; Rutkowska and Jamontt, 2005; Tilley, 2011).

Over the years, a number of population studies that focus on the CNR1 gene and polymorphisms selected because of their possible impact on the functionality of the CB1 receptor, encoded by this gene (Albert, 2011). It is known that both the number encoded by the gene, $\mathrm{CB} 1$ receptors and their function can be changed in response to the altered gene expression in various conditions or disease development, and in response to contact with various substances, including drugs (Laprairie et al., 2012).

\section{Cannabinoid receptor type $2-$ CB2 receptor}

CB2 was first cloned from the human leukemia cell line HL-60 in 1993. The receptor was identified among cDNAs based on its similarity in amino-acid sequence to the $\mathrm{CB} 1$ receptor, discovered in 1990. The discovery of CB2 helps to provide a molecular explanation for the established effects of cannabinoids on the immune system. While the location of the $\mathrm{CB} 1$ receptor is mainly focused in the central nervous system, whereas CB2 receptor is positioned peripherally (Befort, 2015). CB2 receptors are present primarily in the immune system: the spleen, tonsils and in the cells of the immune system, particularly in B cells and NK cells (natural killers), as well as in $\mathrm{T}$ cells, monocytes, macrophages, mast and Hortegi cells (microglia). This location of $\mathrm{CB} 2$ receptors indicates that they are responsible for immunomodulatory properties of cannabinoids. There have also been reports about the presence of these receptors in the retina of adult rats and other animals, and in mouse brain and peripheral nerves of mice and guinea pigs. (Rutkowska and Jamontt, 2005).

Studies suggest that these receptor is also present in small quantities in the several brain structures i.e.: hippocampus, striatum, thalamus, and also into ventral tegmental area neurons (Onaivi et al., 2006; Zhang et al., 2014). There is evidence that points to the role of $\mathrm{CB} 2$ receptor in addictive processes, for example of nicotine (Navarrete et al., 2013).

Recently, there a growing number of new connections between the activity of the CB2 receptor and the occurrence of certain diseases. Furthermore, CB2 receptors are related with malignancies of the immune system and may serve as potential targets for the induction of apoptosis. Also, because CB2 agonists lack psychotropic effects, they may serve as novel anticancer agents to selectively target and kill tumors of immune origin (Mc Kallip et al., 2002). Studies have shown, that the modulation of CB2 receptor signaling may represent a promising therapeutic target that can be used to reduce neuronal degeneration in neurodegenerative diseases, such as Parkinson's, Alzheimer's or Huntington's disease (Cassano et al., 2017). CB2 cannabinoid receptors expressed on malignancies of the immune system may serve as potential targets for the induction of apoptosis (Herrera et al., 2006). Findings also indicate an increased risk of schizophrenia for people with low CB2 receptor function (Ishiquro et al., 2010).

The human CB2 receptor is composed of 360 amino acid residues and a molecular weight of about $40 \mathrm{kDa}$ (GeneCards). The CB2 receptor is a member of the G-protein-coupled receptor family. $\mathrm{CB} 2$ is also a single polypeptide chain of seven hydrophobic transmembrane domains TM I to TM VII, 
which have $\alpha$-helis structure and pass through the cytoplasmic membrane. Its structure contains three extracellular and three intracellular loops. It was found to have an extracellular, glycosylated $\mathrm{N}$ terminus and an intracellular C-terminus too (Figure 3.) (Konarska and Ellert, 2004).

Figure 3. Construction of cannabinoid receptor type $2\left(\mathrm{CB}_{2}\right)$. The numbers at the beginning (1) and end (360) of the chain indicate the direction of numbers of amino acids. Terminal residues, amino (N-) and carboxy (C-), transmembrane domains (TM I-VII), intracellular (ic) and extracellular (ec) loops are also marked.

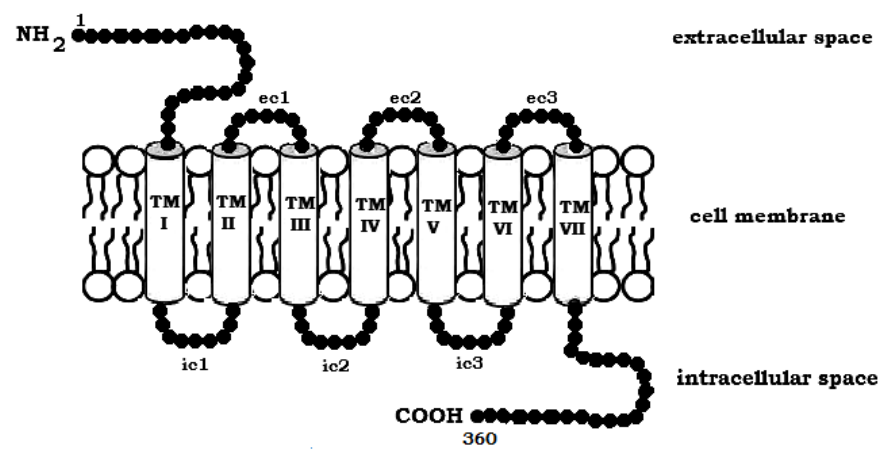

Most known cannabinoid compounds has a similar affinity for both receptor CB2 and CB1, despite differences in their amino acid structures. Compatibility between the amino acid sequences of these (CB1 and $\mathrm{CB} 2$ ) receptors in humans is $48 \%$. It is worth noting that the coding sequences form $\mathrm{CB} 2$ are less conservative than the form CB1 (Konarska and Ellert, 2004; Kazula, 2009).

The CB2 receptor is mainly associated with the regulation of immune response processes. Modification of the receptor activity is associated with impaired cell proliferation and the generation of the defensive response modulators such cytokines. The CB2 receptor stimulation also results in the inhibition of adenylate cyclase (Konarska and Ellert, 2004). Studies showed that in $\mathrm{CHO}$ (Chinese hamster ovary) cells expressing CB2 receptor, cannabinoids activate MAP kinase. The CB2 receptor activation passed through the MAPK is carried out by G-protein subunits $-\gamma$ and $\beta$. One component of this pathway, in contrast to the $\mathrm{CB} 1$ receptor is a $\mathrm{C}$ protein kinase. In the molecular pathway by a signal from CB2 to MAPK may be also involved p21/Ras, Raf-1 and MEK kinase (MAPKK), Anandamide is example for endogenously produced CB2 ligands (Howlett and Mukhopadhyay, 2000; Konarska and Ellert, 2004).

There is growing evidence that selective antagonists of the CB2 cannabinoid receptor inhibit or abolish most of the immunosuppressive effects of cannabinoids. The cannabinoid ligands may be potential therapeutic agent in several pathophysiological situations, so the CB2 cannabinoid receptors have been widely studied in this direction. (Racz et al., 2008). The researchers demonstrated, that in contrast to the $\mathrm{CB} 1$ receptor, the CB2 receptor activation does not affect the ion channels (Pietrzak et al., 2011).

The CB2 partly exerts its effects through initiation of phospholipase $\mathrm{C}$ (PLC) and inositol 1, 4, 5-triphosphate (IP3) signaling pathways that lead to increased levels of intracellular calcium (Zoratti et al., 2003). 


\section{Presumably novel cannabinoid receptors \\ TRPV1 receptor}

TRPV1 (transient receptor potential cation channel subfamily $\mathrm{V}$ member 1) belongs to the transient receptor potential (TRP) family, whose members act as ion channels. The TRP family is divided into subfamilies: TRPC (canonical), TRPV (vanilloid), TRPM (melastatin), TRPP (polycystin), TRPML (mucolipin), TRPA (ankyrin) and TRPN (NOMPC-like). To date, more than 100 TRP-encoding genes have been identified in animals (Clapham, 2005; Nilius, 2011).

TRPV1 is an integral membrane protein, a non-selective cation channel that is gated by a broad array of noxious ligands (GeneBank; Cui, 2016). TRPV1 affects on many functions including inflammation, painful stimuli sensation, and mechanotransduction (Cui, 2016).

The human TRPV1 gene is located on the short arm of chromosome 17 (17p13.2). It consists of 19 exons, includes 43968 bases. The same protein is coding by four transcripts variant. The protein is composed of 839 amino acids and it can be subject to post-translational modifications: phosphorylation by PKA (mainly Ser117), phoshphorylation by CAMKII (regulate binding to vanilloids), glycosylation (Asn 604) (GeneBank; GeneCards). TRPV1 usually occurs as a homotetramer. Whereas it oligomerizes with other TRP receptors (e.g. TRPA1, TRPV3) it functions as promiscuous channel (Staruschenko et al., 2010; Cui, 2016). TRPV1 in the solved state is composed of four symmetrical subunits, and each of them consists of four modules: in the transmembrane region the voltage sensor and pore domain and in the cytosol $-\mathrm{N}$ - and C-terminal modules (Fig. 4.) (Lee et al., 2015; Cui, 2016). The central ion-conducting pore opens up, when ligands are binding. In the $\mathrm{N}$ terminus occur six ankyrin (ANK) repeats (33 amino acids), which serve as binding sites for inhibitors and allow interactions between proteins. There are also several phosphorylation sites (Lishko et al., 2007; Cui, 2016). The C-terminus contains a TRP domain, which encompasses an $\alpha$ helix that runs parallel to the membrane. Moreover, there are a PIP2-binding site, CaM-binding site, and several sites for phosphatases and kinases (Numazaki et al., 2003; Garcia-Sanz et al., 2004; Cui, 2016). In the structure of TRPV1 also occur characteristic dual gates: G1 and G2, whose conformational changes lead to entry into active state (Liao et al., 2013; Cui, 2016).

Figure 4. Construction of TRPV1 receptor. The numbers at the beginning (1) and end (839) of the chain indicate the direction of numbers of amino acids. Terminal residues, amino (N-) and carboxy (C-), transmembrane (TM I-VII) and others domains, intracellular (ic) and extracellular (ec) loops are also marked.

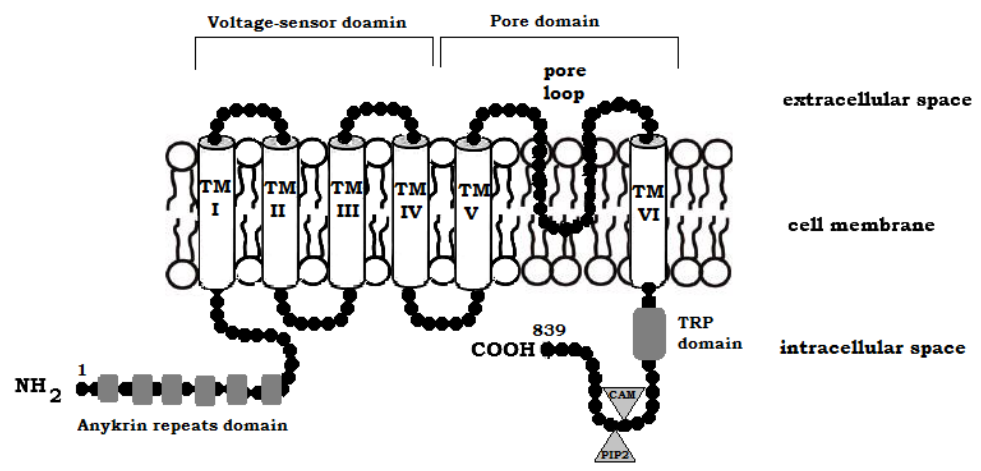


Receptor activity is regulated in response to the binding of specific ligands including CAPS, plant and animal toxins, protons, heat. This is possible through the gating mechanism, which involves structural rearrangements within the channel. The result is a transition from the closed state (nonconducting) to open state (conducting) (Hille, 1978; Cui, 2016).

TRPV1 can be regulated in many ways via interactions with agonists or antagonists. There are a lot of agonists that activate TRVP1 channel. Anandamide was the first identified endogenous TRPV1 agonist (Zygmunt et al., 1999). The group of endogenous agonists includes also lipids derived from the metabolism of arachidonic acid, N-arachidonoylethanolamine (endocannabinoid), $\mathrm{N}-$ arachidonoyldopamine (endocannabinoid), Noleoylethanolamine and $\mathrm{N}$-acylsalsolinols (Appendino, Minassi, Pagani, \& EchChahad, 2008). Several endogenous chemical substances also activate TRPV1: ammonia, adenosine, ATP, protons, ethanol, and polyamines (Szallasi et al., 2007; Cui, 2016). TRPV1 is also induced by a plethora of nonselective stimuli, such as intracellular redox states, acidic $\mathrm{pH}(<5.3)$, heat $\left(>43^{\circ} \mathrm{C}\right)$ and electrostatic charge. CAPS (capsaicin, the substance from hot chilli peppers) and RTX (the substance from black pepper corn) belong to the natural TRPV1 agonists have been studied clinically as potential treatments for inflammatory and neuropathic pain. Furthermore, there are several other naturally occurring agonists for TRPV1 channel including cannabinoids (tetrahydrocannabinol (THC), cannabidiol (CBD) and cannabinol (CBN) (Bisogno et al., 2001; Cui,2016). These findings suggest that TRPV1 receptors might mediate some of the pharmacological effects of CBD and its analogues (Bisogno et al., 2001).

\section{GPR55 (G protein-coupled receptor 55)}

It has been suggested that GPR55 is a novel cannabinoid receptor (Mackie and Stella, 2006). It belongs to a G-proteincoupled receptor superfamily, precisely to the rhodopsin-like (ClassA) family of
TRPV1 antagonists block the receptor channels so they can be treated as an promising therapeutic target. The first TRPV1 antagonist - capsazepine, was created via modifying the chemical backbone of natural agonist capsaicin. Antagonists are subdivided into two types: competitive and noncompetitive. Competitive TRPV1 antagonists bind to the active site and switch TRPV1 channel into closed state. Other competitive antagonists include cinnamide, quinazoline, benzimidazole analogues. In turn, antagonists like tetrabutylammonium and thapsigargin, are classified as noncompetitive when they block pores in receptor by interacting with allosteric sites of the channel (Brito et al., 2014; Cui, 2016).

The functioning of the TRPV1 receptor is involved into several physiological functions, among others: thermo-sensation (heat), autonomic thermoregulation, nociception, pain management, synaptic plasticity in the brain (long-term depression). TRPV1 is also involved in the endocannabinoid signaling in the brain (Nilius, 2011).

Furthermore, expression of the TRPV1 gene is increased in many disorders. Researchers observed the altered expression of the TRPV1 in human preeclamptic placenta (Martínez, 2016). TRPV1 is known to be expressed in peripheral sensory neurons and at lower levels in the spinal cord, brain. Besides neurons, TRPV1 is also expressed a wide-range in non-neuronal cells (e.g. keratinocytes, urothelium, T-cells, mast cells) (Martin, 2008). Therefore the role of TRPV1 in other pathological diseases, for example respiratory- and bladder-related diseases, diabetes, and cancer (Cui, 2016).

GPCRs. This protein plays significant role in signal transduction from the external environment (GeneBank).

The human gene that encodes GPR55 protein is located on the long arm of 
chromosome 2 (2q37.1), encompasses 53,910 bases and contains 4 exons. There are 5 splice variants (GeneCards, GeneBank, Ensmbl). The GPR55 receptor is consists of 319 amino acids and 7 hydrophobic domains characteristic for GPRs. The molecular mass of the protein is $36637 \mathrm{Da}$. (GeneCards, OMIM). It is an integral membrane protein and its structure reminds structure of cannabinoid receptor (GeneBank). The GPR55 is deorphanized as a cannabinoid receptor (Shore and Reggio, 2015).

The amino acid sequence is the most similar to the GPR35 (27\%), P2Y (29\%), GPR23 (30\%), CXCR4 (26\%) but also to CB2 (14.4\%) and CB1 (13.5\%) receptors. Amino acid structure of the human GPR55 is shown on Figure 5. (Sawzdargo et al., 1999; Shore and Reggio, 2015).

Figure 5. Construction of GPR55 receptor. The numbers at the beginning (1) and end (319) of the chain indicate the direction of numbers of amino acids. Terminal residues, amino (N-) and carboxy (C-), transmembrane domains (TM I-VII), intracellular (ic) and extracellular (ec) loops are also marked.

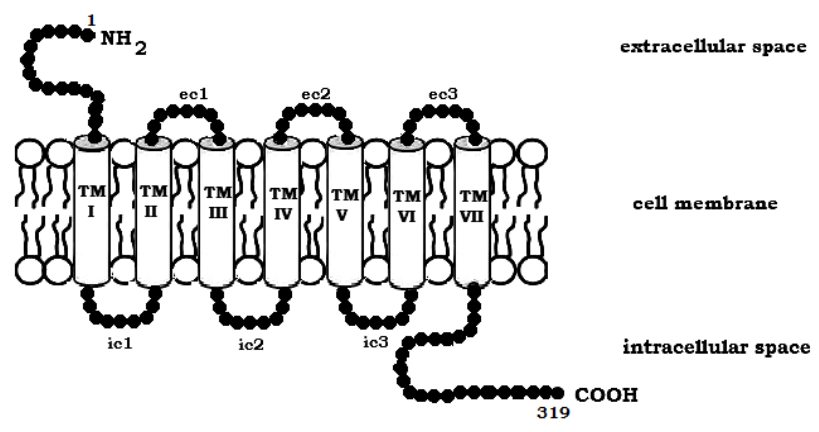

Expression of GPR55 is very high in large dorsal root ganglion neurons. Activation by defined cannabinoids increases amount of intracellular calcium in these neurons. GPR55 activation also inhibits potassium current through M-type potassium channels. It can suggests that activation of GPR55 enhances neuronal excitability (Lauckner et al., 2008). Expression of the GPR55 gene has been observed also in the: central nervous system, adrenal glands, gastrointestinal tract, lung, liver, uterus, bladder, kidney, and bone. The GPR55 receptor is also involved in regulation of energy intake and expenditure. Therefore, this receptor plays a role in the maintenance of energy homeostasis (Simcocks et al., 2014; Shore and Reggio, 2015) In addition, Ryberg et al. analyzed GPR55 receptor ability to bind and to mediate GTP $\gamma \mathrm{S}$ binding by cannabinoid ligands. This analysis showed that GPR55 is activated by endocannabinoids as 2-AG, virodhamine, noladin ether, oleoylethanolamide and palmitoylethanolamide in small concentrations and the atypical cannabinoids Cannabidiol and abnormalcannabidol (synthetic regioisomer of cannabidiol). (Ryberg et al., 2007; Shore and Reggio, 2015).

Above findings establish GPR55 as an additional cannabinoid receptor that can activate signaling pathways distinct from $\mathrm{CB} 1$ or $\mathrm{CB} 2$, and that may increase neuronal excitability and can be involved in nociception, particularly in neuropathic or inflammatory pain states. (Ryberg et al., 2007; Lauckner et al., 2008).

\section{Summary}

The discovery of the cannabinoid receptors in the $1990 \mathrm{~s}$ led to the characterisation of the endogenous cannabinoid system in the context of its composition and many fundamental 
physiological functions. This day understanding of the cannabinoid receptors and other receptors which binds cannabinoids ligands is still not yet fully understood. The existence of additional cannabinoid receptors has long been suspected, due to the effects of some of the compounds causing cannabinoid-like effects on blood pressure and inflammation, but not activating CB1 and CB2 receptors. (Járai et al., 1999; McHugh et al., 2008) Reports suggest that, due to the fact of structural similarity of GPR55 to CB1 and CB2 and sequence homology should be characterized as a third cannabinoid receptor (Ryberg et al. 2007; Johns et al., 2007)

Cannabinoids have a wide spectrum of activity, it exhibits the properties for antiinflammatory, neuroprotective, antiemetic and analgesic effects (McHugh et al., 2008). Studies suggested that they can also relieve intraocular pressure (benefit for glaucoma patients) and have an anti-proliferative effect on cancer cells. According to the National Institute of Health cannabinoids-based medications studies are concentrated on multiple sclerosis research, chronic obstructive pulmonary disease, sickle cell disease, spinal cord injury pain, inflammatory bowel disease (Crohn's disease), cancerrelated pain and brain tumors (U.S. National Institutes of Health, 2013. https://clinicaltrials.gov).
The use of cannabinoids is associated with adverse side effects profile, their action is non-specific, affects the entire central nervous system, causing dizziness, drowsiness, difficulty in concentrating, sleep disturbances and thinking and vision disturbances. In addition, there are also hallucinations, psychosis, depression and tachycardia. After prolonged use of these compounds there is a risk of developing a tolerance to cannabinoids psychotropic activity and any other side effects, which causes significant reduction of the therapeutic indications (Karjnik and Żylicz, 2008) Therefore, more hope for the use of cannabinoids compounds involves the treatment of pathophysiological mechanisms which closely correlate with the endocannabinoid system. There are also suspicions that a deeper understanding of receptors interacting with cannabinoids and its interconnections with the cardiovascular system may be important in the prevention and treatment of diseases of this system (Kazula2009). One way of overcoming the problems associated with the side effect of cannabinoids may be compounds which potentiate the action of endogenous cannabinoids or influence the cannabinoid system indirectly. In this context, gain greater knowledge of receptors interacting with cannabinoids seems to be extremely valuable.

\section{Funding}

This work was supported financially by The National Centre for Research and Development (Grant Number INNOMED/I/ 11/NCBR/2014) from the Innovative Economy Operational Programme founds, in the framework of the European Regional Development Fund.

\section{References}

Adam, J.M., Cairins, J., Caulfield, W., Cowley, P., Cumming, I., Easson, M., Edwards, D., Ferguson, M., Goodwin, R., Jeremiah, F. Kiyoi, T., Mistry, A., Moir, E., Morphy, R., Tierney, J., York, M., Baker, J., Cottney, J.E., Houghton, A.K., Westwood, P.J. \& Walker, G. 2010. Design, synthesis, and structure-activity relationships of indole-3-carboxamides as novel water soluble cannabinoid CB1 receptor agonists. Medicinal Chemistry Communications, 1: 54-60.

Albert, P.R. 2011. What is a functional genetic polymorphism? Defining classes of 
functionality. The Journal of Psychiatry \& Neuroscience, 36(6): 363-365.

Ameri, A. 1999. The effects of cannabinoids on the brain. Progress in Neurobiology, 58(4): 315348.

Befort, K. 2015. Interactions of the opioid and cannabinoid systems in reward: Insights from knockout studies. Frontiers in Pharmacology, 5; 6: 6 .

Bisogno, T., Hanus, L., De Petrocellis, L., Tchilibon, S., Ponde, D.E., Brandi, I., Moriello, A.S., Davis, J.B., Mechoulam, R. \& Di Marzo V. 2001. Molecular targets for cannabidiol and its synthetic analogues: effect on vanilloid VR1 receptors and on the cellular uptake and enzymatic hydrolysis of anandamide. British Journal of Pharmacology, 134(4): 845-852.

Brito, R., Sheth, S., Mukherjea, D., Rybak, L.P., Ramkumar, V. 2014. TRPV1: A Potential Drug Target for Treating Various Diseases. Cells, 3(2):517-545.

Busquets-Garcia, A., Soria-Gomez, E., Bellocchio, L., Marsicano, G. 2016. Cannabinoid receptor type-1: breaking the dogmas. F1000Reseearch, 5, F1000 Faculty Rev-990.

Cabral, G.A. \& Griffin-Thomas, L. 2009. Emerging role of the cannabinoid receptor CB2 in immune regulation: therapeutic prospects for neuroinflammation. Expert Reviews in Molecular Medicine, 20, 11:e3.

Cassano, T., Calcagnini S., Pace, L., De Marco, F., Romano, A., Gaetani, S. 2017. Cannabinoid Receptor 2 Signaling in Neurodegenerative Disorders: From Pathogenesis to a Promising Therapeutic Target. Frontiers in Neuroscience, 11: 30 .

Clapham, D.E., Julius, D., Montell, C., Schultz, G. 2005. Nomenclature and structure-function relationships of transient receptor potential channels. Pharmacological Reviews, 57(4): 427-450.

Cui, M., Gosu, V., Basith, S., Hong, S., Choi, S. 2016. Polymodal Transient Receptor Potential Vanilloid Type 1 Nocisensor: Structure, Modulators, and Therapeutic Applications. Advances in Protein Chemistry and Structural Biology, 104: 81-125.

GeneBank, NCBI. Available from: https://www.ncbi.nlm.nih.gov/gene/7442

GeneBank, NCBI. Available from: https://www.ncbi.nlm.nih.gov/gene/9290

GeneCards. Available from: http://www.genecards.org/cgibin/carddisp.pl?gene $=\mathrm{CNR} 2 \&$ keywords $=\mathrm{cb} 1$

GeneCards. Available from: http://www.genecards.org/cgibin/carddisp.pl?gene $=$ CNR1 \&keywords $=\mathrm{cb} 1$

GeneCards. Available from: http://www.genecards.org/cgibin/carddisp.pl?gene=TRPV1
GeneCards. Available

from: http://www.genecards.org/cgibin/carddisp.pl?gene=GPR55\&keywords $=$ GPR 55

Gunthorpe, M.J., Szallasi, A. 2008. Peripheral TRPV1 Receptors As Targets for Drug Development: New Molecules and Mechanisms. Current Pharmaceutical Design, 14(1): 32-41.

Herrera, B., Carracedo, A., Diez-Zaera, M., Gomez del Pulgar, T., Guzman, M., Velasco, G. 2006. The CB2 cannabinoid receptor signals apoptosis via ceramide-dependent activation of the mitochondrial intrinsic pathway. Experimental Cell Research, 312(11): 2121-2131.

Hille, B. 1978. Ionic channels in excitable membranes. Current problems and biophysical approaches. Biophysical Journal, (2): 283-294.

Howlett, A.C., Mukhopadhyay, S. 2000. Cellular signal transduction by anandamide and 2arachidonoylglycerol. Chemistry and Physics of Lipids, 108(1-2): 53-70.

Ishiguro, H., Horiuchi Y., Ishikawa, M., Koga, M., Imai, K., Suzuki, Y., Morikawa, M., Inada, T. Watanabe, Y., Takahashi, M., Someya, T., Ujike, H., Iwata, N., Ozaki, N., Onaivi, E.S., Kunugi, H., Sasaki, T., Itokawa, M., Arai, M., Niizato, K., Iritani, S., Naka, I., Ohashi, J., Kakita, A., Takahashi, H., Nawa, H., Arinami, T. 2010. Brain cannabinoid CB2 receptor in schizophrenia. Biological Psychiatry, 67(10): 974-982.

Járai, Z, Wagner, J.A., Varga, K., Lake, K.D., Compton, D.R., Martin, B.R., Zimmer, A.M., Bonner, T.I., Buckley, N.E., Mezey, E., Razdan, R.K., Zimmer, A., Kunos, G. 1999. "Cannabinoid-induced mesenteric vasodilation through an endothelial site distinct from CB1 or CB2 receptors. Proceedings of the National Academy of Sciences of the United States of America, 96 (24): 14136-41

Johns, D.G., Behm, D.J., Walker, D.J., Ao, Z., Shapland, E.M., Daniels, D.A., Riddick, M., Dowel,1 S., Staton, P.C., Green, P., Shabon, U., Bao, W., Aiyar, N., Yue, T.L., Brown, A.J., Morrison, A.D., Douglas, S.A. 2007. The novel endocannabinoid receptor GPR55 is activated by atypical cannabinoids but does not mediate their vasodilator effects. British Journal of Pharmacology, 152 (5): 825-31

Kazula, A. 2009. Zastosowanie naturalnych kannabinoidów i endokannabinoidów w terapii. Postępy farmakoterapii, 65(2): 147-160.

Komorowski, J., Stępień, H. 2007. Rola układu endokannabinoidowego $\mathrm{w}$ regulacji czynności dokrewnej i kontroli równowagi energetycznej człowieka. Postępy Higieny Medycyny Doświadczalnej, 61: 99-105.

Konarska, L., Ellert, A. 2004. Receptory kannabinoidowe. In: Nowak, J.Z., Zawilska, 
J.B. (eds). Receptory i mechanizmy przekazywania sygnału. Wydawnictwo Naukowe PWN, pp. 464-490.

Karjnik M., Żylicz Z. 2003. Kannabinoidy w medycynie paliatywnej. Polska Medycyna Paliatywna, 2: 123-131.

Laprairie, R.B., Kelly, M.E., Denovan-Wright, E.M. 2012. The dynamic nature of type 1 cannabinoid receptor (CB1) gene transcription. British Journal of Pharmacology, 167(8): 1583-1595.

Lauckner, J.E., Jensen, J.B., Chen, H.Y., Lu, H.C., Hille, B., Mackie, K. 2008. GPR55 is a cannabinoid receptor that increases intracellular calcium and inhibits $M$ current. Proceedings of the National Academy of Sciences of the United States of America, 105: 2699-2704.

Lee, Y., Hong, S., Cui, M., Sharma, P.K., Lee, J., Choi, S. 2015. Transient receptor potential vanilloid type 1 antagonists: a patent review (2011-2014). Expert Opinion on Therapeutic Patents, 25(3): 291-318.

Liao, M., Cao, E., Julius, D., Cheng Y. 2013. Structure of the TRPV1 ion channel determined by electron cryo-microscopy. Nature, 504: 107112.

Lishko, P.V., Procko, E., Jin, X., Phelps, C.B., Gaudet R. 2007. The Ankyrin Repeats of TRPV1 Bind Multiple Ligands and Modulate Channel Sensitivity. Neuron, 54: 905-918.

Mackie, K., Stella, N. 2006. Cannabinoid receptors and endocannabinoids: evidence for new players. AAPS Journal, 8(2): E298-306.

Martínez, N., Abán, C.E., Leguizamón, G.F., Damiano, A.E., Farina, M.G. 2016. TPRV-1 expression in human preeclamptic placenta. Placenta, 40: 25-28.

McHugh, D., Tanner, C., Mechoulam, R., Pertwee, R.G., Ross, R.A., 2008. Inhibition of human neutrophil chemotaxis by endogenous cannabinoids and phytocannabinoids: evidence for a site distinct from CB1 and CB2. Molecular Pharmacology, 73 (2): 441-50.

McKallip, R.J., Lombard, C., Fisher, M., Martin, B.R., Ryu, S., Grant, S., Nagarkatti, P.S., Nagarkatti M. 2002. Targeting CB2 cannabinoid receptors as a novel therapy to treat malignant lymphoblastic disease. Blood, 100(2): 627-634.

Navarrete, F.., Rodríguez-Arias, M., Martín-García, E., Navarro, D., García-Gutiérrez, M.S., Aguilar, M.A., Aracil-Fernández, A., Berbel, P., Miñarro, J., Maldonado, R., Manzanares, J. 2013. Role of CB2 cannabinoid receptors in the rewarding, reinforcing, and physical effects of nicotine. Neuropsychopharmacology, 38(12): 2515-2524.

Nicoll, G., Davidson, S., Shanley, L., Hing, B., Lear, M., McGuffin, P., Ross, R., MacKenzie, A. 2012. Allele-specific differences in activity of a novel cannabinoid receptor 1 (CNR1) gene intronic enhancer in hypothalamus, dorsal root ganglia, and hippocampus. The Journal of Biological Chemistry, 287(16): 12828-12834.

Nilius, B., Owsianik, G. 2011. The transient receptor potential family of ion channels. Genome Biology, 12(3): 218.0.

Numazaki, M., Tominaga, T., Takeuchi, K., Murayama, N., Toyooka, H., Tominaga, M. 2003. Structural determinant of TRPV1 desensitization interacts with calmodulin. Proceedings of the National Academy of Sciences of the United States of America, 100(13):8002-8006.

Pawlak, M., Łaczmański, Ł., Milewicz, A. 2011. Rola układu endokannabinoidowego i polimorfizmów genu CNR1 w powstawaniu otyłości. Endokrynologia, Otyłość i Zaburzenia Przemiany Materii, 7(3): 192-196.

Pertwee, R.G. 2006. Cannabinoid pharmacology: the first 66 years. British Journal of Pharmacology, 147: $163-171$.

Pertwee, R.G. 2009. Emerging strategies for exploiting cannabinoid receptor agonists as medicines. British Journal of Pharmacology, 156(3): 397-411.

Pietrzak, B., Dunaj, A., Piątkowska, K. 2011. Rola układu kannabinoidowego w patogenezie oraz poszukiwaniu nowych możliwości farmakoterapii zespołu zależności alkoholowej. Postępy Higieny Medycyny Doświadczalnej, 65: 606-615.

Racz, I., Nadal, X., Alferink, J., Baños, J.E., Rehnelt, J., Martín, M., Pintado, B., GutierrezAdan, A., Sanguino, E., Manzanares, J., Zimmer, A., Maldonado, R. 2008. Crucial Role of CB2 cannabinoid receptor in the regulation of central immune responses during neuropathic pain. Journal of Neuroscience, 28(46): 1212512135.

Rutkowska, M., Jamontt, J. 2005. Rola układu kannabinoidowego w fizjologii i patofizjologii ośrodkowego układu nerwowego. Advances in Clinical and Experimental Medicine, 14(6): 1243-1252.

Ryberg, E., Vu, H.K., Larsson, N., Groblewski, T., Hjorth, S., Elebring, T., Sjögren, S., Greasley, P.J. 2005. Identification and characterisation of novel splice variant of the human CB1 receptor. FEBS Letters, 579(1): 259-264.

Ryberg, E., Larsson, N., Sjögren, S., Hjorth, S., Hermansson, N.O., Leonova, J., Elebring, T., Nilsson, K., Drmota, T. \& Greasley, P.J. 2007. The orphan receptor GPR55 is a novel cannabinoid receptor. British Journal of Pharmacology, 152(7): 1092-1101.

Sawzdargo, M., Nguyen, T., Lee, D.K., Lynch, K.R., Cheng, R., Heng, H.H., George, S.R., O’Dowd, B.F. 1999. Identification and cloning of three novel human $\mathrm{G}$ protein-coupled receptor genes GPR52, PsiGPR53 and GPR55: GPR55 is 
extensively expressed in human brain. Brain research. Molecular brain research, 64(2): 193198.

Shire, D., Carillon, C., Kaghad, M., Calandra, B., Rinaldi-Carmona, M., Le Fur, G., Caput, D., Ferrara, P. 1995. An amino-terminal variant of the central cannabinoid receptor resulting from alternative splicing. The Journal of Biological Chemistry, 270(3): 3726-3731.

Shore, D.M., Reggio, P.H. 2015. The therapeutic potential of orphan GPCRs, GPR35 and GPR55. Frontiers in Pharmacology, 6: 69.

Simcocks, A.C., O’keefe, L., Jenkin, K.A., Mathai, M.L., Hryciw, D.H., Mcainch, A.J. 2014. A potential role for GPR55 in the regulation of energy homeostasis. Drug Discovery Today, 19:1145-1151.

Staruschenko, A., Jeske, N.A., Akopian, A.N. 2010. Contribution of TRPV1-TRPA1 Interaction to the Single Channel Properties of the TRPA1 Channel. The Journal of Biological Chemistry, 285: $15167-15177$.

Sullivan, J.M. 2000. Cellular and molecular mechanisms underlying learning and memory imrairments produced by cannabinoids. Learning \& Memory, 7(3): 132-139.

Szallasi, A., Cortright, D.N., Blum, C.A., Eid, S.R. 2007, The vanilloid receptor TRPV1: 10 years from channel cloning to antagonist proof-ofconcept. Nature Reviews Drug Discovery, 6: 357-372.

Tilley, D.G. 2011. G protein-dependent and G protein-independent signaling pathways and their impact on cardiac function. Circulation Research, 109(2): 217-230.

U.S. National Institutes of Health, 2013. https://clinicaltrials.gov

Zhang, H.Y., Gao, M., Liu, Q.R., Bi, G.H., Li, X., Yang, H.J., Gardner, E.L., Wu, J., Xi, Z.X. 2014. Cannabinoid CB2 receptors modulate midbrain dopamine neuronal activity and dopamine-related behavior in mice. Proceedings of the National Academy of Sciences of the United States of America, 111(46): E5007-15.

Zoratti, C., Kipmen-Korgun, D., Osibow, K., Malli, R., Graier, W.F. 2003. Anandamide initiates $\mathrm{Ca}(2+)$ signaling via $\mathrm{CB} 2$ receptor linked to phospholipase $\mathrm{C}$ in calf pulmonary endothelial cells. British Journal of Pharmacology, 140(8): 1351-1362.

Zygmunt, P.M., Petersson, J., Andersson, D.A., Chuang, H.H., Sørgård, M., Di Marzo, V., Julius, D., Högestätt, E.D. 1999. Vanilloid receptors on sensory nerves mediate the vasodilator action of anandamide. Nature, 400: $452-457$.

\section{Streszczenie}

Układ endokannabinoidowy (ang. endocannabinoid stystem-ECS) składa się z receptorów kannabinoidowych CB1 i CB2, agonistów egzogennych i endogennych: kannabinoidów i endokannabinoidów oraz enzymów regulujące syntezę i degradację endogennych ligandów tego układu. Jest systemem biorącym udział w wielu procesach fizjologicznych organizmu. Odgrywa on istotną rolę w prawidłowym funkcjonowaniu centralnego i autonomicznego układu nerwowego. Układ endokannabinoidowy reguluje również m.in. gospodarkę energetyczną, aktywność motoryczną, układ endokrynny oraz układ hormonalny poprzez regulacje powiązań neurohormonalnych i neuroimmunologicznych. Wiele jego wspomnianych funkcji związanych jest $\mathrm{z}$ receptorami sprzężonymi z białkami G, takimi jak receptory CB1, CB2 czy GPR55. Co raz więcej mówi się również o znaczącej roli receptorów przejściowego potencjału TRPs (ang. transient receptor potential), które nie tylko pośredniczą w odczuwaniu bólu, ale także są odpowiedzialne za wspomaganie stanu zapalnego poprzez wydzielanie prozapalnych neuropeptydów.

W niniejszej pracy przeglądowej postanowiliśmy krótko scharakteryzować oraz opisać rolę i działanie receptorów kannabinoidowych CB1 i CB2, receptora sprzężonego z białkiem G (GPR55) i receptora przejściowego potencjału waniloidowego (TRPV1). 